\title{
CRYSTALLINE INCLUSIONS IN CHROMITES FROM KIMBERLITES AND LAMPROITES.
}

A.M. Logvinova and N.V. Sobolev.

Institute of Mineralogy and Petrography 630090 Novosibirsk, USSR

A comparative study of inclusions in chrome spinel macrocrysts (more than $0.5 \mathrm{~mm}$ ) extracted from heavy concentrates of several kimberlite pipes of Yakutia (Udachnaya, Ailkhal, Mir, International) and lamproites of western Australia (Ellendale 4 pipe) have been performed. Out of 1000 spinel grains from kimberlites and 700 grains from lamproites solid inclusions have been identified respectively in $20 \%$ and $10 \%$ of all examined grains. More than $60 \%$ of all inclusions are heavily altered.

Olivines are the most abundant inclusions for both rock types being found in 57 out of 70 chromite grains containing unaltered inclusions. Chrome diopside was fixed in 3 grains, enstatite in 2 grains, pyrope in 5 grains including one of lamproitic chrome spinel.

Kimberlitic spinels with inclusions contain from 0.06 to $3.02 \mathrm{wt} \% \mathrm{TiO}_{2}$, from 36.3 to 64.3 wt $\% \mathrm{Cr}_{2} \mathrm{O}_{3}$, from 9.2 to $16.6 \mathrm{wt} \% \mathrm{MgO}$. Lamproitic spinels contain from 0.16 tp 3.16 wt $\% \mathrm{TiO}_{2}$, from 38.3 to 58.5 wt $\% \mathrm{Cr}_{2} \mathrm{O}_{3}$, from 11 to 13 wt $\% \mathrm{MgO}$.

Crystalline inclusions from kimberlitic chromites are represented mainly by crystals with well developed octahedral faces, being similar to most inclusions in diamonds by their negative diamond (or chromite) morphology.

Both olivines, pyroxenes and pyrope inclusions from lamproitic spinels are highly resorbed and are rounded.

Olivine included in chrome spinels from kimberlites are containing $89-94 \mathrm{~mol} \%$ Fo. One chromite grain from Udachnaya pipe with $49.5 \mathrm{wt} \% \mathrm{Cr}_{2} \mathrm{O}_{3}, 5.3 \mathrm{wt} \% \mathrm{Al}_{2} \mathrm{O}_{3}, 3.0 \mathrm{wt} \% \mathrm{TiO}_{2}$ contains two olivine inclusions with 89 and $92 \mathrm{~mol} \%$ Fo. Olivine included in lamproitic spinel has a narrower range of Fo: from 88 to $90 \mathrm{~mol} \%$.

Pyrope presence in one of chromite grains from lamproite $\left(7.3 \mathrm{wt} \% \mathrm{Cr}_{2} \mathrm{O}_{3}, 6, .4 \mathrm{wt} \%\right.$ $\mathrm{CaO})$ and in four grains of kimberlitic spinels $\left(\mathrm{Cr}_{2} \mathrm{O}_{3}\right.$ from 2.0 to $6.9 \mathrm{wt} \%, \mathrm{CaO}$ frm 3.9 to 9.6 wt $\%$ ) indicates along with some chrome-diopside inclusions lherzolitic and also one wherlitic parageneses of the studied chromite grains.

Temperature estimate for $30 \mathrm{kbar}$ pressure using O'Neill and Wall (1987) approach have shown a range from 790 to $1020^{\circ} \mathrm{C}$ for all kimberlitic chromites (Av. $914^{\circ} \mathrm{C}$ for 37 samples) and from 1010 to $1140^{\circ} \mathrm{C}$ for lamproite spinels (Av. $1062^{\circ} \mathrm{C}$ for 21 samples). A significant higher equilibration temperature is observed for chromite-olivine pairs from lamproite compared with those of a number of Yakutian kimberlites. 